\title{
II Hiszpańsko-Polskie Dni Laparoskopii Onkologicznej w Cáceres w hiszpańskiej Estremadurze
}

W dniach 14-15 maja 2015 roku odbyły się drugie już hiszpańsko-plskie warsztaty zaawansowanych technik laparoskopowych w onkologii zabiegowej, zorganizowane przez Centrum Onkologii — Instytut im. Marii Skłodowskiej-Curie, Oddział w Krakowie przy współpracy z Centrum Chirurgii Minimalnie Inwazyjnej w Cáceres w Hiszpanii. W szkoleniu wzięli udział chirurdzy, ginekolodzy i onkolodzy z polskich ośrodków onkologicznych.

Warsztaty otworzyli kierwonicy naukowi kursu: dr Andrzej Komorowski z Krakowa i dr Francisco Miguel Sánchez Margallo z Cáceres. Część teoretyczna kursu obejmowała wykłady z zakresu ergonomii laparoskopowej, anatomii zwierząt doświadczalnych oraz nowowczesnych technik poprawiających wyniki uczenia (analiza modalna błędów). Następnie uczestnicy rozpoczęli dwudniowy maraton zajęć praktycznych na zwierzętach doświadczalnych oraz symulatorach. Każdy uczestnik miał wybrane i dostosowane do swojej specjalności ćwiczenia, zarówno na żywym mo- delu zwierzęcym świni, jak i na wcześniej przygotowanych preparatach zwierzęcych. Zakres procedur chirurgicznych, które zostały wykonane podczas dwóch dni kursu na żywych modelach świńskich, obejmował cholecystektomię, hemihepatektomię, resekcję jelita cienkiego, resekcję lewej połowy okrężnicy oraz zespolenia jelitowe. Na trenażerach laparoskopowych doskonalono różne techniki zespoleń laparoskopowych. Ćwiczenia ze specjalizacji urologicznej dotyczyły wykonania zespoleń cewkowo-pęcherzowych, zabiegów organooszczędzających nerkę oraz nefrektomii na modelu świńskim. Procedury ginekologiczne dotyczyły ćwiczeń z zakresu limfadenektomii biodrowej zarówno na żywym modelu zwierzęcym, jak i na preparatach, oraz wycięcia jajników. Nad prawidłowym przebiegiem warsztatów czuwał zespół doświadczonych laparoskopistów z Centrum Chirurgii Minimalnie Inwazyjnej oraz Instytutu Onkologii w Krakowie. W razie jakichkolwiek problemów lub wątpliwości podczas pracy na trenażerach oraz przy

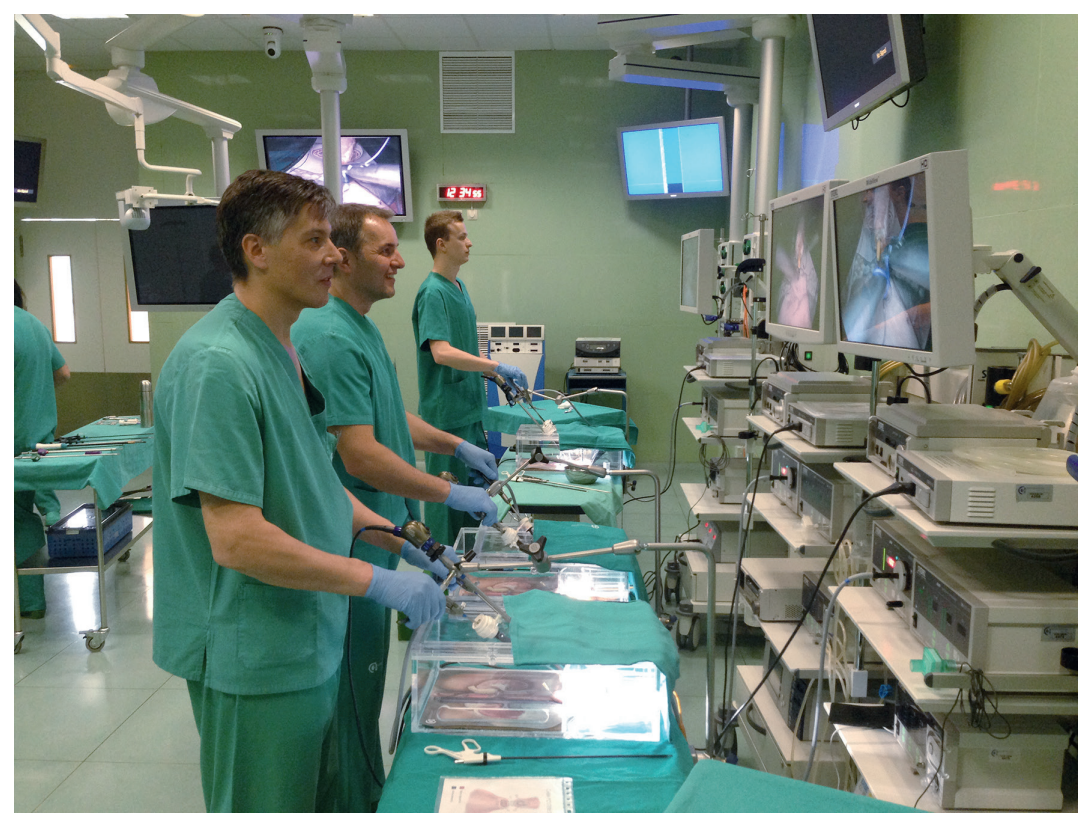

Rycina 1. Uczestnicy kursu podczas pracy na trenażerach laparoskopowych 


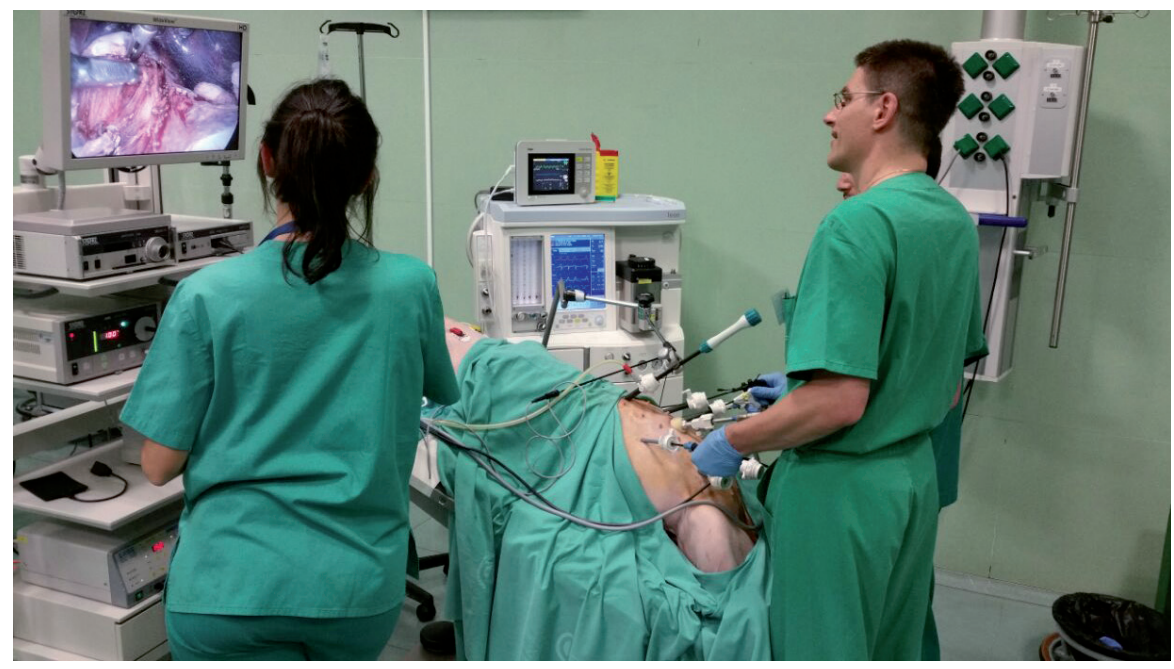

Rycina 2. Ćwiczenia na żywym modelu świńskim

znieczulonym modelu świńskim udzielali cennych porad i wskazówek. Warto zaznaczyć, że każdy uczestnik pracował na innym stanowisku laparoskopowym, tak że po 10 godzinach ćwiczeń w ciągu jednego dnia można było odczuć zmęczenie, i tym cenniejsze stawały się wskazówki dotyczące ergonomii laparoskopowej, które uczestnicy otrzymali na początku kursu.

Techniki laparoskopowe objęte programem pozwoliły na wyćwiczenie kluczowych elementów zabiegów danej specjalności, uwzględniając ich przydatność w codziennej pracy.

Odbywające się w Cáceres warsztaty laparoskopowe stanowią nieoceniony element nauczania i doskonalenia tej trudnej techniki zabiegowej. Jednocześnie średniowieczne centrum Cáceres, wpisane na listę UNESCO, stanowiło wspaniałe tło kursu, a fakt, że miasto otrzymało w roku 2015 zaszczytny tytuł Hiszpańskiej Stolicy Gastronomicznej, był dodatkową atrakcją dla zmęczonych po intensywnym szkoleniu uczestników kursu.

\section{Dr n. med. Jerzy Władysław Mituś}

Centrum Onkologii — Instytut im. Marii Skłodowskiej-Curie, Oddział w Krakowie

Katedra Anatomii, Uniwersytet Jagielloński,

Collegium Medicum w Krakowie

e-mail:jerzy.mitus@gmail.com 